\title{
Spatial dynamics of the red grouper Epinephelus morio (Pisces: Serranidae) on the Campeche Bank, Gulf of Mexico
}

\author{
JORGE A. LÓPEZ-ROCHA ${ }^{1}$ and FRANCISCO ARREGUÍN-SÁNCHEZ ${ }^{2}$ \\ ${ }^{1}$ Unidad Multidisciplinaria de Docencia e Investigación, Facultad de Ciencias, Universidad Nacional Autónoma de \\ México, Puerto de abrigo s/n. Sisal, Yucatan, C.P. 97130, Mexico. E-mail: jorgelopezrocha@ciencias.unam.mx \\ ${ }^{2}$ CICIMAR-Instituto Politécnico Nacional, A.P. 592, La Paz, Baja California Sur 23000, México.
}

\begin{abstract}
SUMMARY: The spatial dynamics of the red grouper Epinephelus morio plays a fundamental role in the fishery management on the Campeche Bank, where it is overfished. The objective of this study was to characterize the spatial dynamics of this population. We used a dynamic model of spatial distribution to estimate population movement rates between adjacent areas. The model was applied using information on catch per unit effort and length-frequency distributions for the Mexican midsized fleet that operated in the area in the period 1973-1977. These data were chosen to ensure that the information would reflect the condition of the resource before overfishing. It was possible to quantify the spatial dynamics of the red grouper and the results were consistent with previously known movement patterns. The results showed different movement rates and temporal patterns of movement for different population sectors. The spawning aggregations and the seasonal upwelling occurring in the eastern part of the Bank were considered as key factors influencing the pattern of population movements.
\end{abstract}

Keywords: red grouper, distribution, spatial model, movement rates, spatial variations, temporal distribution.

RESUMEN: Dinámica espacial del mero Epinephelus morio (Pisces: Serranidae) en el Banco de Campeche, Golfo de MéXICo. - La población del mero rojo Epinephelus morio del Banco de Campeche está sobreexplotada. La dinámica espacial del mero juega un papel fundamental en la gestión de la pesquería. El objetivo de este estudio fue caracterizar la dinámica espacial de la población del mero en el Banco de Campeche. Se utilizó un modelo dinámico de distribución espacial para estimar tasas de movimiento poblacional entre áreas adyacentes. El modelo se aplicó con información de las capturas por unidad de esfuerzo y de distribuciones de frecuencias de longitud provenientes de la flota mediana mexicana que operó en la zona de 1973 a 1977. Estos datos fueron elegidos para asegurar que la información reflejara el estado del recurso antes de la sobrepesca. Fue posible cuantificar la dinámica espacial del mero y los resultados concordaron con patrones de movimientos conocidos anteriormente. Los resultados mostraron distintos patrones temporales de movimiento para los diferentes sectores de población. Se considera que las agregaciones de desove y la surgencia estacional que ocurre en la parte oriental del Banco son factores clave que influyen en el patrón de los movimientos de población.

Palabras clave: mero, distribución, modelo espacial, tasas de movimiento, variaciones espaciales, distribución temporal.

\section{INTRODUCTION}

The red grouper Epinephelus morio Valenciennes 1928 is demersal and highly territorial. It is distributed from Katama Bay, Massachusetts, USA to Rio de Janeiro, Brazil (Moe 1969). This benthic species prefers habitats associated with tropical water temperatures (above $20^{\circ} \mathrm{C}$ ). Data from research cruises indicate that the red grouper is abundant in waters with tempera- tures of $23^{\circ} \mathrm{C}$ to $25^{\circ} \mathrm{C}$ and that the species is not caught at temperatures below $16^{\circ} \mathrm{C}$ (Gonzalez et al. 1974). The two most important populations with the highest abundances are located in the Gulf of Mexico on the west coast of Florida and on the Campeche Bank north of the Yucatan Peninsula (Moe 1969).

The red grouper population on the Campeche Bank has been exploited commercially since the 1940s. The fishery is economically important to the region, but 
the population is now overfished (Burgos-Rosas and Pérez-Pérez 2006). The fishery includes a small-scale fleet composed of approximately 1800 outboard vessels distributed along the coast of the Yucatan Peninsula (Burgos-Rosas and Pérez-Pérez 2006): a mid-sized fleet based in Progreso, Yucatan, consisting of 515 vessels with a length of 10 to $22 \mathrm{~m}$, each of which has an average of eight "alijos" (non-motorized dinghies from which an angler operates one longline); and a Cuban fleet with nine vessels with a length of 22 m equipped with six small vessels each, from which two fishermen operate one longline (Giménez-Hurtado 2005).

The red grouper moves seasonally throughout its range. On the Campeche Bank, its abundance increases during the winter and early spring in the eastern region of the continental shelf (Valdés and Padrón 1980, Arreguín-Sánchez 1992, Arreguín-Sánchez et al. 1997, Arreguín-Sánchez and Pitcher 1999, Hernández and Seijo 2003). This increase has been linked primarily to the reproductive season in late winter and early spring (Zetina-Moguel et al. 1996, Brulé et al. 1999, Giménez et al. 2003). The catchability of the red grouper also increases during the winter (Arreguín-Sánchez 1992, Arreguín-Sánchez et al. 1996, Arreguín-Sánchez and Pitcher 1999) and in specific western and eastern areas of the Campeche Bank (López-Rocha and ArreguínSánchez 2008), which have been mainly associated with spawning aggregations.

Several species of grouper tend to form spawning aggregations in specific areas each year (Shapiro 1987, Sadovy 1996). Ehrhardt and Deleveaux (2007) mention that $E$. striatus forms seasonal aggregations for spawning and can move for days or even weeks to reach the spawning site (Domeier and Colin 1997). An increase in average length with increasing depth has been documented for the populations of Florida and the Carolinas (Moe 1969, Rivas 1970, Burgos et al. 2007) and off the Campeche Bank (González et al. 1974, Valdés and Padrón 1980, Arreguín-Sánchez 1992, Giménez-Hurtado 2005). This pattern has been attributed to an ontogenetic migration. The juveniles remain close to the coast and begin to move towards deeper areas when they reach maturity (Moe 1969, Sluka et al. 1994, Burgos et al. 2007). ArreguínSánchez (1992) also suggests that the immature individuals have a west-east movement that is synchronized with the movement of adults but that the immatures tend to remain near the coast.

It is clear that the effective management of the fishery must recognize the spatial dynamics of the red grouper, especially of the overfished Campeche Bank population. Fishing restrictions have been suggested for certain areas to protect the critical habitat of this population, including its areas of spawning aggregation and its juvenile nursery areas.

Because the available evidence shows that the red grouper population on the Campeche Bank moves seasonally, this paper analyses the pattern of population movements using a dynamic model of spatial distribu- tion that estimates population movement rates between adjacent areas. To obtain unbiased estimates in view of the possible impact of overfishing, this analysis uses data for the period 1972 to 1977 . In this period the resource is considered to have been exploited to the maximum degree possible without producing deterioration (Arreguín-Sánchez et al. 1997).

Spatial dynamics of fish stocks has been studied mainly by mark-recapture methods. The main focus of these methods has often been the estimation of growth rates, movement patterns and stock delineation (Polacheck et al. 2010). Besides the conventional tags, the electronic and acoustic tags provide a powerful way to estimate migration rates. Furthermore, individual-based models have been applied (e.g., Huse and Giske 1998, Okunishi et al. 2012). Besides the models developed for mark-recapture data, interesting approaches are that of MacCall (1990) on movement rates based on habitat suitability gradients and that of Apostolaki et al. (2002), which included movement coefficients in a model for assessing the effects of a reserve area.

This paper proposes a new model, which is based on the concept that the net difference of abundance between adjacent areas and at successive times reflects the movement of organisms between these areas. The model considers in each spatial unit the population structure, instantaneous rates of fishing and natural mortality, catchability with sources of variation (time, age and area) and the carrying capacity of each unit area.

\section{MATERIALS AND METHODS}

\section{Data}

To estimate the temporal patterns of movement of the red grouper, we used a 15-year database (19731987) on the catch and effort (in effective fishing days: EFD) of the Mexican mid-sized fleet and the lengthfrequency distributions associated with each fishing trip. Through an exploratory analysis of the database, we found that the period 1973 to 1977 was the best represented both spatially and temporally. This period (686 fishing trips) was used to estimate the movement pattern of the population. During this period, the highest catches of red grouper were recorded, and the population was not overfished (Arreguín-Sánchez et al. 1997). Therefore, the information obtained reflects the population behaviour rather than the dynamics of the fleet.

The continental shelf of the northern Yucatan Peninsula (Campeche Bank) was divided into cells $\left(0.5^{\circ}\right.$ latitude $\times 0.5^{\circ}$ longitude) representing the basic spatial unit for estimating the displacement of individuals (Fig. 1). The analysis used the following quarterly time units: December-February (winter); March-May (spring); June-August (summer); and September-November (autumn). 


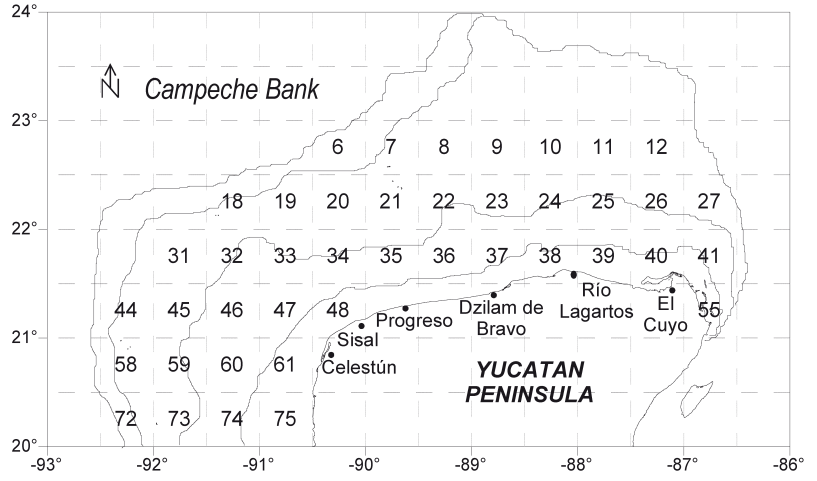

FIG. 1. - Study area (Campeche Bank) divided into cells $\left(0.5^{\circ}\right.$ latitude $\times 0.5^{\circ}$ longitude) for the estimation of E. morio movement patterns.

\section{Dynamic model of spatial distribution}

The analysis of the spatial dynamics of the red grouper uses a dynamic model of the spatial distribution of the population. The model derivation assumes that the carrying capacity for a population is determined by the amount of habitat available, which can be altered by physical agents. The growth of an exploited population may be characterized by the logistic growth curve (Schaefer 1954, 1957):

$$
P_{t+1}=P_{t}\left[1+r-\left(P_{t} / K\right)-q f_{t}\right]
$$

where $P$ is the population size in number of individuals; $r$ is the intrinsic growth rate; $q$ is the catchability coefficient; $f$ is the fishing effort; $t$ is time; and $K$ is the carrying capacity, given by the equation

$$
K=\lambda \sum_{i=1}^{n} h_{i, t} \delta_{i}
$$

where $h_{i, t}$ is the proportion of area of the habitat $i$ available at time $t ; \delta_{i}$ is the relative density of individuals in habitat $i ; h_{i, t} \delta_{i}$ is the population relative abundance corresponding to the area defined by $h_{i, t}$ (habitat) at time $t$ $\left(=H_{i, t}\right) ; \lambda$ is a constant; and $K / \lambda$ is the carrying capacity proportional to each $h_{i, t}$.

Generally, the individuals in a population occupy different niches at different stages of the life cycle. These niches are often associated with the occupation of various habitats. If individuals in the population at a given time $t$ are evenly distributed in space without any segregation, then

from which it follows that

$$
\begin{gathered}
\delta_{i}=\delta_{i+1}=\cdots=\delta_{n} \\
h_{i, t}=h_{i+1, t}=\cdots=h_{n, t}
\end{gathered}
$$

and therefore $\lambda=K$.

$$
\sum_{i=1}^{n} h_{i, t} \delta_{i}=1
$$

If the conditions stated in Equation (3) are not met, then specific estimates of each $H_{i, t}$ are needed. These values can be obtained by assuming that the area involved in each estimate $H_{i, t}$ has a fixed probability, $s$, of containing (or receiving) a certain number of individuals (or recruits) during each unit of time $t$ and that each individual has a fixed probability, $D$, of death per unit time.

The analysis incorporated the structure of the population by considering three sectors: juveniles $(J)$ associated with a size range $T L_{1} \leq T L_{J} \leq T L_{m i n}$, pre-adults $(P)$ associated with a size range $T L_{m i n} \leq T L_{P} \leq T L_{m 50}$ and adults (A) associated with a size range $T L_{m 50} \leq T L_{A} \leq T L_{\max }$, where $T L_{1}$ is the size of the smallest juveniles in the catch $(20 \mathrm{~cm}$ in total length $T L) ; T L_{\min }$ is the size of the smallest mature females $(30 \mathrm{~cm} T L$ ) (Giménez et al. 2003); $T L_{m 50}$ is the estimated size at which $50 \%$ of the population reaches maturity $(51 \mathrm{~cm} T L)$ (Brulé et al. 1999); and $T L_{\max }$ is the maximum size found in the population $(89 \mathrm{~cm} T L)$. In this way we can represent the proportion of individuals per population sector that occupy a certain area as:

$$
\begin{aligned}
& H_{i, J, t}=1-\prod_{T L_{1}}^{T L \min ^{-1}}\left[1-s_{i, k, t} e^{-D t}\right] \\
& H_{i, P, t}=1-\prod_{t_{\min }}^{T L_{m s o-1}}\left[1-s_{i, k, t} e^{-D t}\right] \\
& H_{i, A, t}=1-\prod_{T L_{\text {mso }}}^{T L_{\max }}\left[1-s_{i, k, t} e^{-D t}\right]
\end{aligned}
$$

where $H_{i, J, t}$ is the proportion of juveniles in area $i$ at time $t ; H_{i, P, t}$ is the proportion of pre-adults in area $i$ at time $t ; H_{i, A, t}$ is the proportion of adults in area $i$ at time $t ; s_{i, k, t}$ is the probability that area $i$ contains (or receives) individuals of the population sector $k$ at time $t ; D=$ $M_{k}+q_{k, i, t} * f_{i, t} ; M_{k}$ is the natural mortality rate of the population sector $k ; q_{k, i, t}$ is the catchability coefficient of the population sector $k$ in area $i$ at time $t$; and $f_{i, t}$ is the fishing effort in EFD in area $i$ at time $t$.

Equation (4) can be used to analyse population movement patterns, such as those resulting from migrations or major population movements. For example, assuming that a sector of the population $(k)$ moves from area $i$ to area $z$ within a certain time interval $(t, t+1)$, the movement rate $\left(\mu_{k, i, z}\right)$ can be expressed as

$$
\frac{d}{d t}\left(H_{k, i \rightarrow z}\right)=\mu_{k, i, z}
$$

We estimated the number of individuals in each area with a catch equation of the form

$$
N_{i, k, t}=C_{i, k, t} / q_{i, k, t}\left(f_{i, t}\right)
$$

where $N_{i, k, t}$ is the size of population sector $k$ in area $i$ at time $t ; C_{i, k, t}$ is the catch in area $i$ of population sector $k$ at time $t ; q_{i, k, t}$ is the catchability in area $i$ of population sector $k$ at time $t$; and $f_{i, t}$ is the fishing effort in area $i$ at time $t$.

The estimated $N_{i, k, t}$ was weighted by the proportion of individuals estimated (Eq. 4). The number of individuals leaving area $i$ at time $t$ to arrive in area $z$ at time $t+1$ was calculated as

$$
N_{\left(i_{t} \rightarrow z_{t+1}\right) k}=N_{i, k, t} e^{\mu_{k, i, z}}
$$


where $N_{\left(i_{t} \rightarrow z_{t+1}\right) k}$ is the number of individuals of population sector $k$ leaving area $i$ at time $t$ to arrive in area $z$ at time $t+1$, and $\mu_{k, i, z}$ is the movement rate of population sector $k$ leaving the area $i$ at time $t$ to arrive in area $z$ at time $t+1$.

Individuals of each area $i$ (donor area) have a maximum of four possible directions of movement (north, south, east and west) towards immediately adjacent areas (receiving areas). Therefore, the total number of individuals emerging from donor area $i\left(N_{t o t\left(i_{t} \rightarrow z_{t+1}\right) k}\right)$ does not exceed the number of individuals in area $i\left(N_{i, k, t}\right)$.

$$
N_{t o t\left(i_{t} \rightarrow z_{t+1}\right) k} \leq N_{i, k, t}
$$

where $N_{\text {tot }\left(i_{t} \rightarrow z_{t+1}\right) k}$ is the sum of the number of individuals leaving area $i$ in the four possible directions.

If the sum of the number of individuals leaving area $i$ exceeded the population size of the area and individuals moved in more than one direction, the choice was made to prioritize the movement direction with a higher movement rate.

The total number of individuals recruited to an area $i$ is the sum of the movements to the area from the four adjacent areas added to the survivors in the same area $i$. This value is limited only by the specific carrying capacity of each area $i\left(K_{i}\right)$.

$$
K_{i}=\operatorname{Umax}_{i} / 0.95
$$

where $K_{i}$ is the carrying capacity of area $i$.

Therefore, the number of individuals that come from different areas $i$ to area $z$, plus surviving individuals in area $z$, must be less than or equal to the carrying capacity of area $z$.

$$
N_{\left(i_{t} \rightarrow z_{t+1}\right) k+} N_{z, k, t} \leq K_{z}
$$

If the number of individuals that come from different areas $i$ to area $z$ exceeds the carrying capacity of area $z$, the remaining individuals are redirected to one of the areas adjacent to the donor area $i$. The area to which the individuals are redirected is that area with the highest value of the probability $s$ (the probability of an area to contain or receive individuals).

\section{Model parameters}

The probability of containing (or receiving) individuals $\left(s_{i, k, t}\right)$ of Equation (4) was calculated as

$$
s_{i, k, t}=U_{i, k, t} / \operatorname{Umax}_{i}
$$

where $U_{i, k, t}$ is the catch per unit effort (number of individuals/EFD) of population sector $k$ in area $i$ at time $t$, and $U \max _{i}$ is the maximum catch per unit effort (number of individuals/EFD) in area $i$.

The values used for the natural mortality rate $(M)$ were $1.21,0.45$ and 0.22 year $^{-1}$ for juveniles, pre-adults and adults, respectively. These values were estimated by the gnomonic intervals method (Giménez-Hurtado 2005).

Variable catchability values by sector of population, area and time were taken from estimates made with the Leslie transition matrix (Shepherd 1987, Caswell 1988) by López-Rocha and Arreguín-Sánchez (2008) and López-Rocha et al. (2009). These estimates were made for the same period of time and with the same spatial resolution as this study and consist in catchability values varying by size, time and space.

The estimate of catchability starts by considering the equation $N(\ell, t+1)=A(\ell, k) N(\ell, t)$, where $k$ and $\ell$ are successive length intervals; $N(\ell, t)$ is stock size at time $t$ (year), here represented by length-frequency distribution expressed as catch per unit effort; $A$ is a transition matrix, which depends on growth and mortality and is expressed as the product of two terms (Shepherd, 1987): $A(\ell, k)=G(\ell, k) S(k)$, where $G(\ell, k)$ is a matrix representing the effect of growth in the absence of mortality; and $S(k)$ is a matrix representing survival and effect of the sampling selection gear. The $G(\ell, k)$ matrix was estimated by assigning probability of growth to each size class according to Shepherd (1987). The survival matrix $S(k)$ can be expressed in terms of mortality as $S(k)=\exp -z(k, t)=\exp -[M+q(k, t) s(k) E(t)]$, where $Z(k, t)$ is instantaneous rate of total mortality for the $k^{\text {th }}$ length group at time $t ; M$ is the natural mortality, assumed as constant over size and time; $s(k)$ is the fishing gear probability of selection for the $k^{\text {th }}$ length group; $E(t)$ is fishing effort at time $t$; and $q(k, t)$ is catchability for the $k^{\text {th }}$ length group at time $t$. Fishing mortality is given as $F(k, t)=q(k, t) s(k) E(t)$. Since $S(k), M, s(k)$, and $E(t)$ are known, $q(k, t)$ was estimated by solving the survival equation with an iterative procedure (LópezRocha and Arreguín-Sánchez 2008).

\section{Spatial representation of movement rates}

For the representation of trends or patterns of movements, the kriging interpolation method (Cressie 1991) was applied with specific variograms by population sector and season. Interpolation and spatial representation were conducted with the Surfer program (version 8).

\section{RESULTS}

Table 1 shows the average estimates of the proportion of individuals $\left(H_{i, k, t}\right)$, movement rates $\left(\mu_{k, i, z}\right)$, number of individuals in each area $\left(N_{i, k, t}\right)$ and number of moving individuals (NMI) for each season and population sector. It is observed that the proportion of individuals per area $\left(H_{i, k, t}\right)$ was consistently higher in pre-adults and was therefore the sector of the population that had the highest movement rates. Movement rates $\left(\mu_{k, i, z}\right)$ of adults were higher in autumn-winter and winter-spring and there was a decrease in the average movement rates in the last two years of the study period, though this does not apply to juveniles and preadults. Similarly, the proportion of individuals $\left(H_{i, k, t}\right)$ 
TABLE 1. - Average values of movement rates in proportion of individuals/quarter $\left(\mu_{k, i, z}\right)$, proportion of individuals per area $\left(H_{i, k, t}\right)$, number of individuals per area $\left(N_{i, k, t}\right)$ and number of moving individuals $(N M I)$ of the red grouper E. morio on the Campeche Bank, Gulf of Mexico. Ad., adults; P-ad., pre-adults; J., Juveniles.

\begin{tabular}{|c|c|c|c|c|c|c|c|c|c|c|c|c|}
\hline \multirow[b]{2}{*}{ Season } & \multicolumn{3}{|c|}{ Movement rate $\left(\mu_{k, i, z}\right)$} & \multicolumn{3}{|c|}{ Proportion $\left(H_{i, k, t}\right)$} & \multicolumn{3}{|c|}{ Number of individuals $\left(N_{i, k, t}\right)$} & \multirow[b]{2}{*}{ Ad. } & \multirow{2}{*}{$\begin{array}{l}N M I \\
\text { P-ad. }\end{array}$} & \multirow[b]{2}{*}{ J. } \\
\hline & Ad. & P-ad. & & Ad. & P-ad. & $\mathrm{J}$ & Ad. & P-ad. & & & & \\
\hline Winter-spring (73) & 0.521 & 0.441 & 0.185 & 0.381 & 0.202 & 0.036 & 40987 & 98121 & 473 & 16721 & 495 & 26 \\
\hline Spring-summer (73) & 607 & 1.453 & 0.223 & & 0.168 & 0.012 & 36421 & 75249 & 612 & 10032 & 23120 & 0 \\
\hline Summer-autumn (73) & 0.575 & 1.622 & 0.519 & 0.260 & 0.310 & 0.035 & 51805 & 231401 & 1315 & 7431 & 103370 & 583 \\
\hline Autumn-winter (73) & 0.520 & 0.316 & 0.501 & 191 & 0.637 & 0.117 & 22899 & 376162 & 18855 & 3222 & 43820 & 4333 \\
\hline Average & 0.556 & 0.958 & 0.357 & 0.290 & 0.329 & 0.050 & 38028 & 195233 & 5314 & 9351 & 42701 & 1236 \\
\hline Winter-spring (74) & 0.726 & 1.414 & 0.777 & 0.254 & 0.297 & 0.065 & 20245 & 88760 & 13767 & 2564 & 1775 & 5118 \\
\hline Spring-sum & 588 & 1.607 & 0.437 & 379 & 0.342 & 0.064 & 144065 & 277305 & 9494 & 24576 & 103839 & 442 \\
\hline Summer-autumn (74) & 0.260 & 0.821 & 0.887 & 286 & 0.475 & 0.111 & 117106 & 753823 & 17283 & 414 & 56287 & 5170 \\
\hline Autumn-winter (74) & 0.522 & 0.934 & 0.461 & 0.162 & 0.567 & 0.214 & 18590 & 696920 & 115307 & 8877 & 154688 & 5810 \\
\hline Average & 0.524 & 1.194 & 0.640 & 0.270 & 0.420 & 0.113 & 75002 & 454202 & 38963 & 9108 & 79147 & 4135 \\
\hline Winter-spring (75) & .566 & & 0.225 & 0.217 & 0.175 & 0.048 & 43124 & & 2796 & 1575 & 2434 & 94 \\
\hline Sprir & 375 & 1.112 & 0.350 & 184 & 0.2 & $0.02-2$ & 207 & 63235 & 261 & 8727 & 35035 & 102 \\
\hline Summer-autumn (75) & 0.537 & 1.507 & 0.314 & 211 & 0.337 & 0.033 & 73788 & 462486 & 1042 & 4380 & 112814 & 206 \\
\hline er (75) & 0.698 & 0.897 & 0.064 & 52 & 0.5 & 7 & 178 & 302 & 16373 & 1776 & 43476 & \\
\hline Average & 0.544 & 1.244 & 0.238 & 0.216 & 0.317 & 0.042 & 38883 & 212543 & 5707 & 4114 & 48440 & 101 \\
\hline Wintel & & & & 16 & & & & & & 39 & & 71 \\
\hline Spring-summer (76) & 0.388 & 0.771 & 0.174 & 0.124 & 0.375 & 0.065 & 6938 & 101508 & 14413 & 420 & 8391 & 157 \\
\hline Summer-autumn (76) & 0.192 & 1.191 & 0.389 & 0.147 & 0.322 & 0.039 & 13220 & 419630 & 3271 & 586 & 79655 & 2123 \\
\hline Autumn-winter (76) & 0.206 & 0.997 & 0.182 & 0.073 & 0.508 & 0.097 & 1906 & 282110 & 94280 & 151 & 42735 & 82 \\
\hline Average & 0.241 & 0.966 & 0.245 & 0.126 & 0.389 & 0.056 & 6528 & 222756 & 28084 & 299 & 43728 & 608 \\
\hline Winter-spring (77) & 0.209 & & 0.236 & 0.065 & & 0.065 & 1175 & & 1965 & 0 & & 13 \\
\hline Spring-summer (77) & 0.248 & 0.642 & 0.098 & & 0.50 & 0.103 & 8552 & 177005 & 10115 & 261 & 22277 & 22 \\
\hline Summer-autumn (77) & 0.367 & 1.765 & 0.584 & 0.095 & 0.336 & 0.024 & 6537 & 255646 & 937 & 373 & 99686 & 202 \\
\hline Autumn-winter (77) & & & & 0.081 & 0.584 & 0.102 & 11258 & 313309 & 4613 & & & \\
\hline Average & 0.275 & 1.193 & 0.306 & 0.104 & 0.492 & 0.074 & 6881 & 214821 & 4407 & 211 & 45652 & 79 \\
\hline
\end{tabular}

of adults consistently decreased from the first to the last year.

Figure 2 shows that the pre-adults had the highest movement rates, followed by the adults and juveniles. The lowest values of the rate of movement of adults occurred in winter-spring, spring-summer and summerautumn. An increase occurred in autumn-winter. The average movement rates of the pre-adults were highest in spring-summer and summer-autumn and decreased in winter-spring and autumn-winter. The juveniles had higher movement rates in summer-autumn.

The most noteworthy feature of the pattern of adult movements was the movement occurring in the eastern part of the continental shelf in winter-spring (Fig. 3), primarily from south to north. This pattern can be observed in four of the five years studied. In two years, movements occurred in the western part of the continental shelf at high rates compared with those occurring in the eastern part of the shelf.

In spring-summer, substantial movements of individuals occurred in the western part of the bank. These movements occurred from the central part of the continental shelf to the western part of the shelf. The eastern part of the shelf was dominated by south-north movements similar to those observed in winter-spring, but of a lesser magnitude. Movements of individuals in summer-autumn occurred over most of the Bank. On the eastern continental shelf, the movement was primarily towards the west. The movement in the central area was generally towards the north. However, in

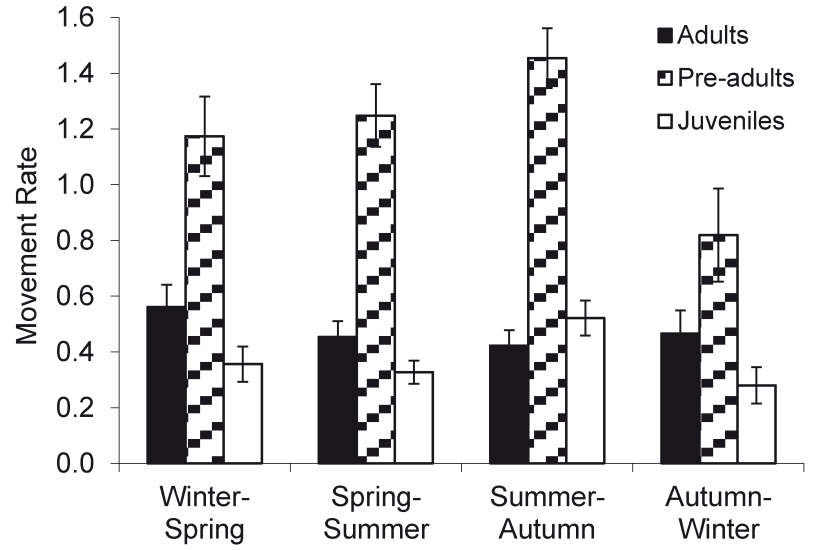

FIG. 2. - Average movement rates by population sector and season of E. morio in the Campeche Bank, Gulf of Mexico. Movement rate $\left(\mu_{k, i, z}\right)$ in proportion of individuals per quarter $\left(H_{i, k, l}\right.$ /quarter). Lines represent standard error.

1974 and 1976 the movement was towards the south. In autumn-winter, a marked movement on the central and western continental shelf occurred at a high rate towards the north and northwest. On the eastern continental shelf, the movement rates were mostly low towards the northwest (Fig. 3).

The pre-adults moved towards the south in winterspring (Fig. 4), in the opposite direction from the adults, which moved to the north. In spring-summer, a movement pattern westward on the central and western continental shelf was evident. At the eastern end of the 

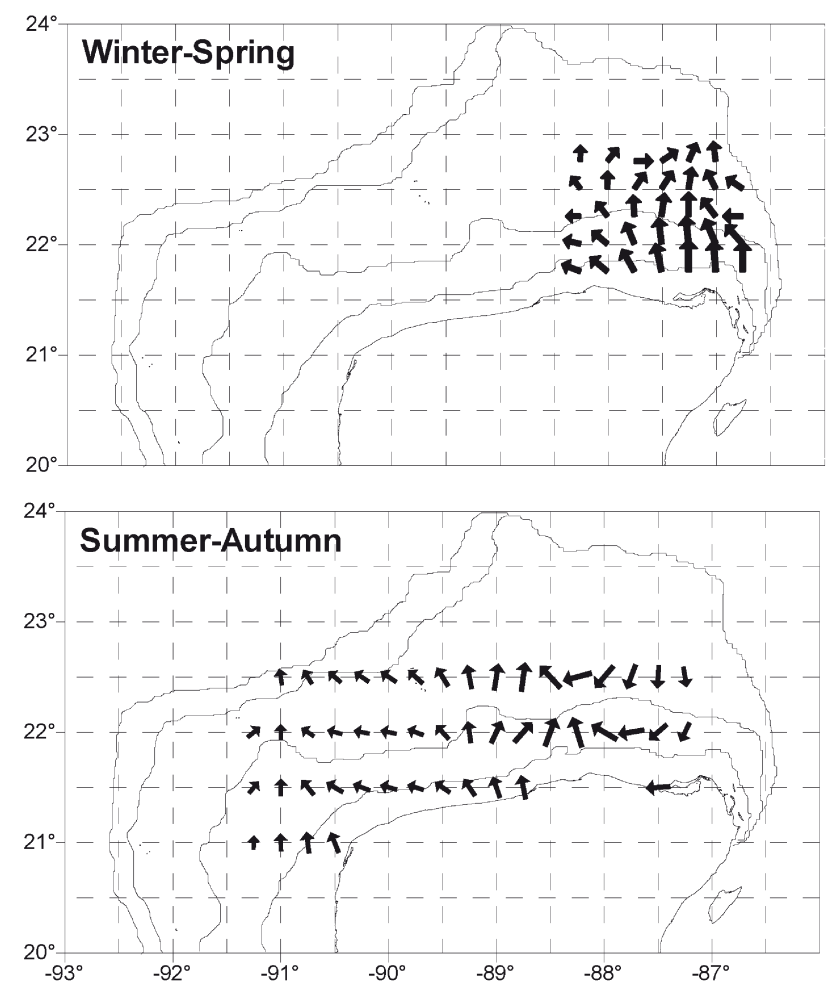
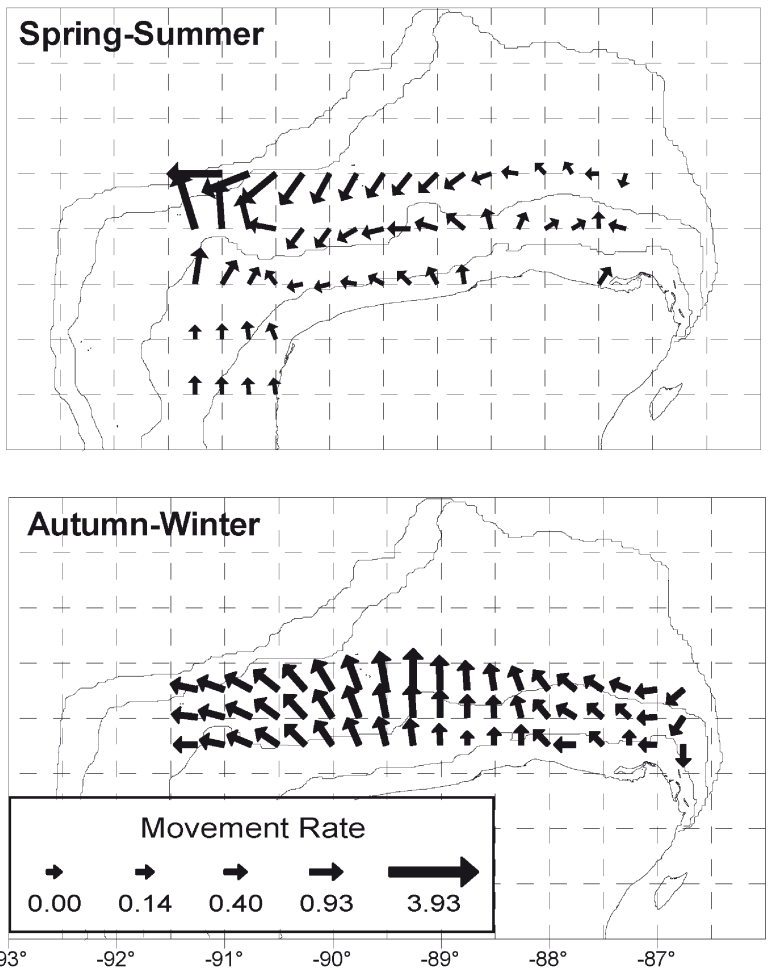

FIG. 3. - Major features of the movement pattern of adult red grouper E. morio in the Campeche Bank, Gulf of Mexico a) in winter and spring (1973); b) in spring and summer (1974); c) in summer and autumn (1973); and d) in autumn and winter (1974). Movement rate $\left(\mu_{k, i, z}\right)$ in proportion of individuals per quarter $\left(H_{i, k, t} /\right.$ quarter $)$.
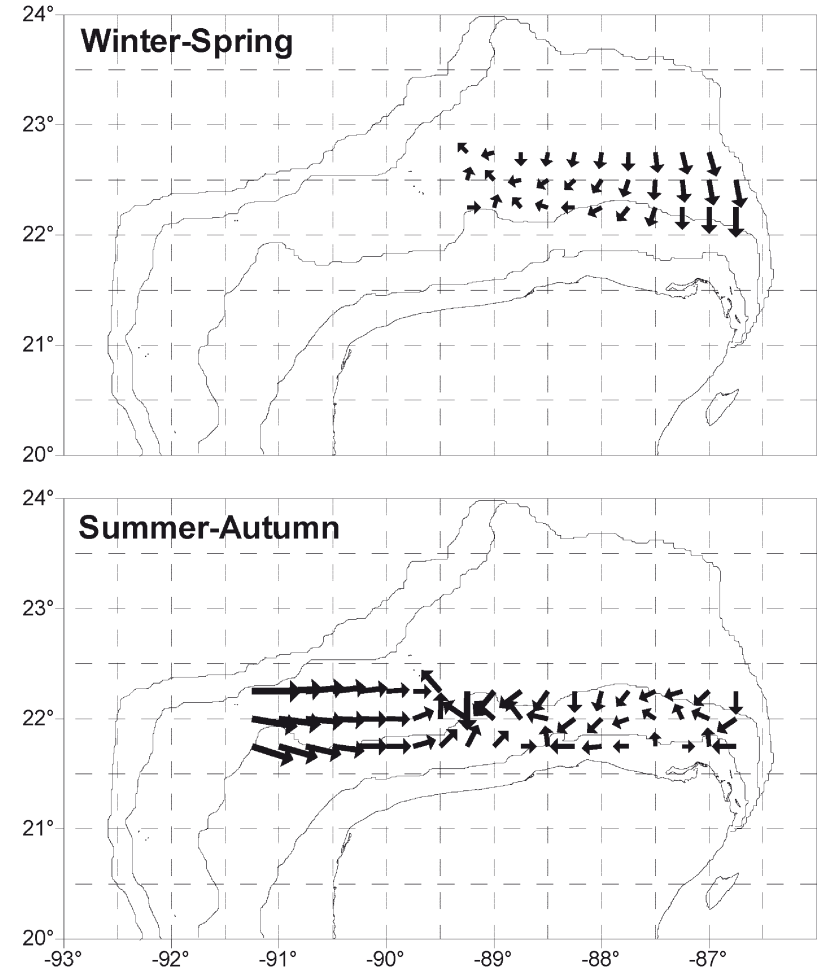
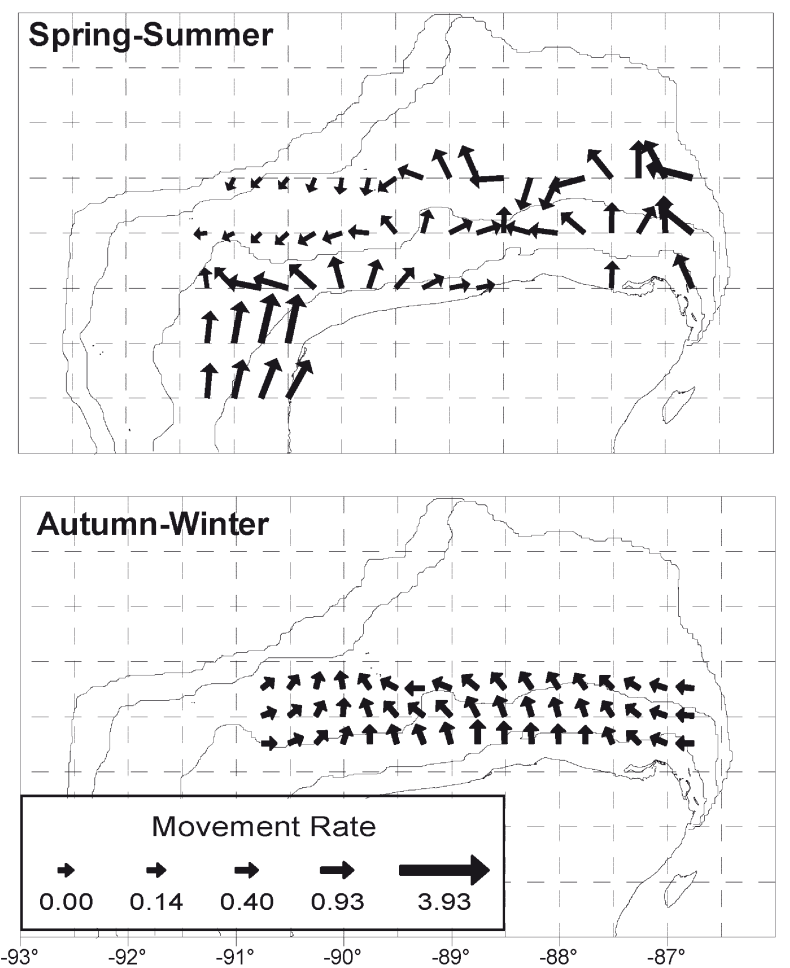

FIG. 4. - Major features of the movement pattern of pre-adult red grouper E. morio in the Campeche Bank, Gulf of Mexico a) in winter and spring (1973); b) in spring and summer (1974); c) in summer and autumn (1974); and d) in autumn and winter (1975). Movement rate $\left(\mu_{k, i, z}\right)$ in proportion of individuals per quarter $\left(H_{i, k, t} /\right.$ quarter $)$. 

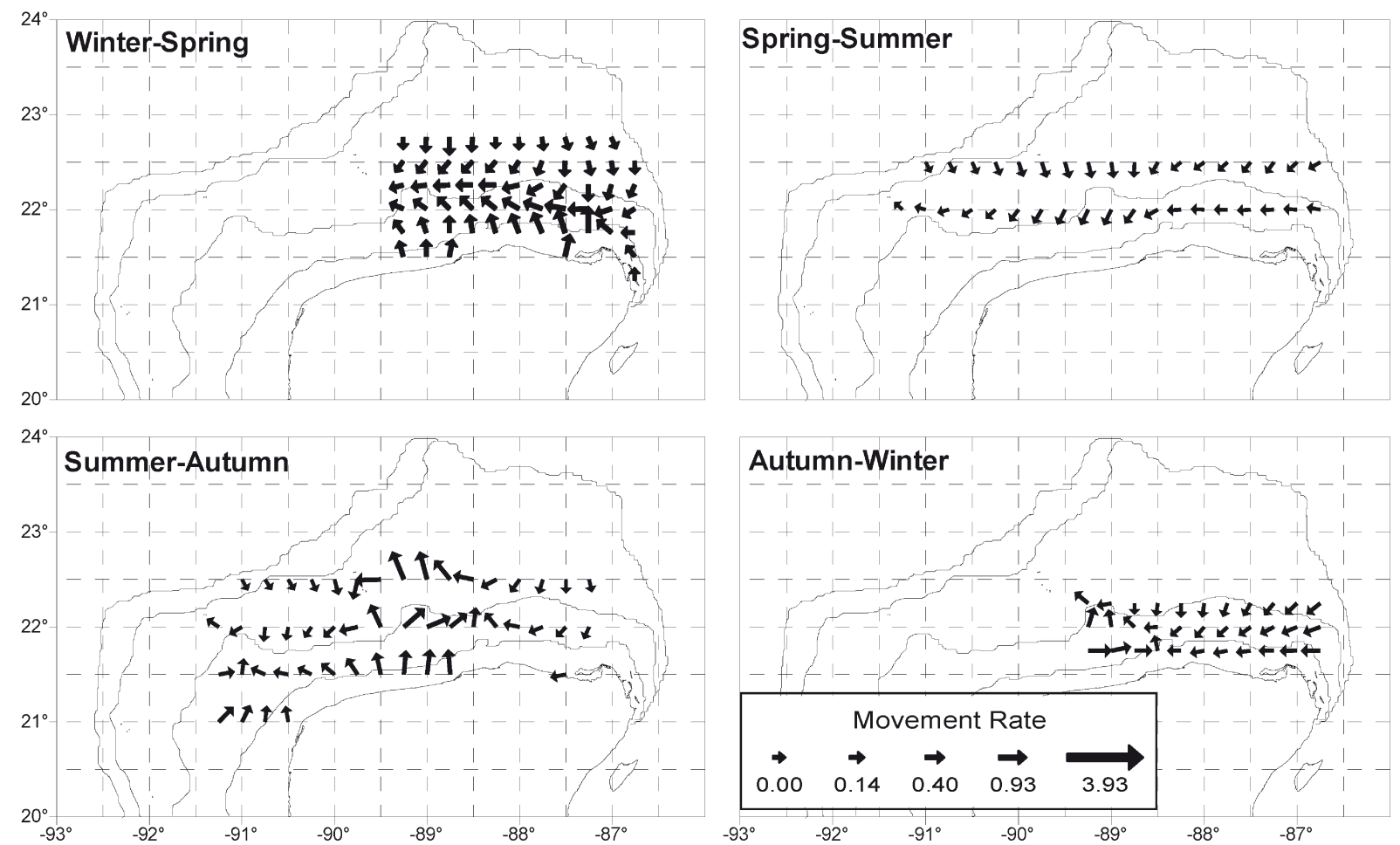

FIG. 5. - Major features in the movement pattern of juvenile red grouper E. morio in the Campeche Bank, Gulf of Mexico a) in winter and spring (1975); b) in spring and summer (1973); c) in summer and autumn (1973); and d) in autumn and winter (1973). Movement rate $\left(\mu_{k, i, z}\right)$ in proportion of individuals per quarter $\left(H_{i, k, l} /\right.$ quarter $)$

continental shelf and in the southwestern region of the shelf, the movements were primarily towards the north. In summer-autumn, intense movements occurred over most of the bank. The dominant movement pattern was eastward from the western continental shelf and westward from the eastern shelf. In autumn-winter, the primary movements occurred from south to north at low rates (Fig. 4).

In winter-spring, the juveniles on the southeastern continental shelf moved towards the south. This movement was similar to that of the pre-adults but contrary to that of the adults. On the central and western continental shelf, the movement pattern was primarily westward. In spring-summer, the movement pattern was primarily south-westward. In some years, a northward movement was observed in the western part of the continental shelf. The most dynamic movements of the juveniles were observed in summer-fall. A northward movement occurred in the central area, whereas the dominant movement was westward in the eastern region. In autumn-winter, movements occurred near Rio Lagartos and the Dzilam Bravo coast. The movements towards these areas occurred from the east and west (Fig. 5).

\section{DISCUSSION}

The results of this study reveal that the spatial dynamics of the red grouper are more complex than had been previously suggested. González et al.(1974), Valdés and
Padrón (1980), Arreguín-Sánchez and Pitcher (1999) and Burgos-Rosas and Pérez-Pérez (2006) observed that the red grouper population exhibits a displacement towards the east during the winter and towards the west during the summer. Arreguín-Sánchez (1992) and Arreguín-Sánchez et al. $(1996,1997)$ observed that the juveniles follow the same pattern but always remain near the coast. The results of this study generally confirm this pattern of east-west movement. However, the current analysis defines the movements of the red grouper in considerably greater detail. The study showed that these movements are differentiated by developmental stage and that the movements of the juveniles also occur in areas that are not adjacent to the coast.

The reproductive period in late winter and early spring can be viewed as the fundamental element of the movement pattern of the adults. Unlike other grouper species (Shapiro 1987, Sadovy 1996), red grouper have not been reported to form large and conspicuous spawning aggregations. It is likely that they spawn in small groups distributed over fairly large areas (Coleman et al. 1996). However, the occurrence of the highest abundances during the winter in the eastern part of the Campeche Bank (Valdés and Padrón 1980, Arreguín-Sánchez and Pitcher 1999, Burgos-Rosas and Pérez-Pérez 2006) and the increases in catchability during the winter and in specific areas of the eastern bank (Arreguín-Sánchez and Pitcher 1999, López-Rocha and Arreguín-Sánchez 2008) identify this region as the principal area for red grouper reproduction. 
The red grouper aggregation on the eastern continental shelf has been explained by the thermal conditions near the bottom and the upwelling of cold water masses that occurs with greater intensity on the eastern Bank during the spring (Vasiliev and Serrano 1973, Arreguín-Sánchez 1992, Piñeiro and Giménez 2001). Giménez-Hurtado et al. (2003) note that one of the factors necessary for spawning is a temperature of approximately $22^{\circ} \mathrm{C}$. Temperatures in this range occur on the eastern continental shelf from March to May.

Arreguín-Sánchez et al. (1997) cited an east-west displacement of the juveniles near the coast associated with the movement of the adults. However, the current study also observed northward movements of juveniles in deep areas in summer and autumn (Fig. $5)$. This result is consistent with the estimates of the catchability anomalies during the autumn (LópezRocha et al. 2009). The dominance of negative anomalies in these estimates indicates a higher catchability of small fishes, even in the deeper regions. This result suggests that although juveniles tend to live and move in shallow areas near the coast, they also move northward to deeper areas, primarily during the autumn. Consistent with this hypothesis, Giménez-Hurtado (2005) reported that the highest proportion of individuals with a total length of less than $30 \mathrm{~cm}$ was found at depths between 10 and $20 \mathrm{~m}$ but that fishes of this size were found in smaller proportions at depths up to $60 \mathrm{~m}$.

Moe (1969) reported that immature red grouper inhabit regions near the coast and move to deeper water at maturity. The findings of this study suggest that in addition to this ontogenetic migration, juveniles move towards deeper areas in summer and autumn. Moreover, Burgos et al. (2007), based on observations on the distribution of the female red grouper population in the waters of North and South Carolina, proposed that massive annual migrations occur between offshore spawning areas and coastal areas. These authors hypothesized that the females prefer a shallow habitat and that when they reach sexual maturity they move to deeper areas to form spawning aggregations. After spawning, the females return to shallow areas. This pattern may be consistent with our finding that the adults move primarily from the shallow areas to deeper water in autumn and winter (Fig. 3). Movements to spawning areas are expected in these seasons.

The movement rates of the juveniles were low throughout the year. This finding indicates that the juveniles were less active than the rest of the population. The juvenile movements that occur in autumn and winter indicate a pattern of grouping in shallow areas near Dzilam de Bravo and Rio Lagartos, Yucatan. This result demonstrates the importance of these areas as a habitat for the juveniles. The preferred habitat of juvenile red grouper is seagrasses and coastal reefs (Moe 1969, Sluka et al. 1994). These areas are similar to those reported by Renan et al. (2003) as potential breeding areas for different species of groupers.
The movement rates of adults did not differ significantly between seasons (ANOVA, $\mathrm{P}>0.05$ ). However, the occurrence of the highest movement rates in winter and spring ( 0.5632 adult proportion ${ }_{A} H /$ quarter) and in autumn and winter (0.4654 adult proportion ${ }_{A} H$ /quarter) may reflect the active spatial dynamics occurring before and after the principal spawning period.

The general pattern of movement of adults in spring and summer is westward (Fig. 3). This tendency reflects the end of the period of spawning aggregations and the dispersal of individuals along the continental shelf. The general population movement towards the west may be related to the findings of García (1976), who mentions that red grouper react adversely to sudden decreases in temperature. If cold water is present, the grouper leave their usual locations. If they are aggregated, as they are during the spawning period, they tend to disperse. Therefore, movements likely represent a response to the cold waters that are moving westward from the Contoy area.

The estimated movement rates in autumn and winter $\left(\mu_{k, i, z}=0.4654\right.$ individuals/quarter $)$ were the second highest for adults $\left(\mu_{k, i, z}=0.5603\right.$ individuals/quarter for winter-spring). Theoretically, a marked movement from west to east is expected in this season in conjunction with the movement to the spawning areas. However, no such movement was evident. On the eastern bank, individuals moved into areas that have been identified as spawning areas (Fig. 3). During this period, a major movement occurred towards the western bank. This finding may indicate that individuals moved to spawning aggregation areas on the northwestern bank. Brulé and Deniel (1996) suggest that red grouper spawn in various areas distributed throughout the Campeche Bank.

Inclusion of variable catchability by population sector, time and space was fundamental to the proper performance of the model to estimate movement rates. Red grouper catchability variability along the Campeche Bank has been documented: for example, increasing catchability for adults during the winter in the eastern bank (López-Rocha and Arreguín-Sánchez 2008, López-Rocha et al. 2009). The inclusion of these sources of variation reveals that differences in the relative abundance index, in this case the catch per unit effort, are actually due to movements of individuals rather than variations in catchability. In this case, it was not necessary to standardize catch per unit effort because there were no significant changes in the fishing power during the study period.

The performance of the model depended in part on the parameter $s$, the probability that a given habitat contained or received a certain number of individuals. This parameter was estimated relative to the maximum abundance found in the area (Eq. 6). However, a more appropriate estimation method would need to relate this parameter to one or more environmental variables. Such a solution would take into account the preference of red grouper for certain bottom features (AlbañezLucero and Arreguín-Sánchez 2009). 
The temporal patterns of red grouper movement found in this study may contribute useful information for the exploration of new population management measures, such as the restriction of fishing in certain areas.

\section{ACKNOWLEDGEMENTS}

The authors acknowledge support through the project SEP-CONACYT (104974), ANR-CONACYT (111465), GEF-UNIDO-SEMARNAT-NOAA LMEGolfo de México, SIP-IPN (20131266) and Incofish (EU-003739). JL is grateful to CONACYT for a scholarship for postgraduate studies. FAS is grateful to the IPN for its support through its programmes and COFAA EDI.

\section{REFERENCES}

Albáñez-Lucero M.O., Arreguín-Sánchez F. 2009. Modelling spatial distribution of red grouper (Epinephelus morio) at Campeche Bank, México, with respect substrate. Ecol. Model. 220: 2744-2750.

Apostolaki P., Milner-Gulland E.J., McAllister M.K., Kirkwood G.P. 2002. Modelling the effects of establishing a marine reserve for mobile fish species. Can. J. Fish. Aquat. Sci. 59: 405-415.

Arreguín-Sánchez F. 1992. An approach to the study of the catchability coefficient with application to the red grouper (Epinephelus morio) fishery from the continental shelf of $\mathrm{Yu}$ catan, Mexico. PhD thesis, CINVESTAV-IPN, Unidad Mérida, México, $222 \mathrm{pp}$.

Arreguín-Sánchez F., Contreras M., Moreno V., Valdés R., Burgos R. 1997. La pesquería de mero (Epinephelus morio) de la Sonda de Campeche, México. In: Flores-Hernández D., Sánchez-Gil P., Seijo J. C., Arreguín-Sánchez F. (eds), Análisis y Diagnóstico de los Recursos Pesqueros Críticos del Golfo de México. Universidad Autónoma de Campeche, EPOMEX Serie Científica, pp. 307-332.

Arreguín-Sánchez F., Contreras M., Moreno V., Burgos R., Valdés R. 1996. Population dynamics and stock assessment of the red grouper (Epinephelus morio) fishery on Campeche Bank, Mexico. In: Arreguín-Sánchez F., Munro J.L., Balgos M., Pauly D. (eds), Biology of Grouper and Snappers. ICLARM Proc. pp. 202-217.

Arreguín-Sánchez F., Pitcher T.J. 1999. Catchability estimates accounting for several sources of variation: application to the red grouper fishery of the Campeche Bank, México. Fish. Bull. 97 : 746-757.

Brulé T., Déniel C. 1996. Biological research on the red grouper (Epinephelus morio) from the southern Gulf of Mexico. In: Arreguín-Sánchez F., Munro J. L., Balgos M., Pauly D. (eds), Biology of Grouper and Snappers. ICLARM Proc. pp. 28-42.

Brulé T., Déniel C., Colás-Marrufo T., Sánchez-Crespo M. 1999. Red Grouper reproduction in the southern Gulf of Mexico. T. Am. Fish. Soc. 128: 385-402.

Burgos J.M., Sedberry G.R., Wyanski D.M., Harris P.J. 2007. Life history of red grouper (Epinephelus morio) off the coasts of North Carolina and South Carolina. Bull. Mar. Sci. 80: 45-65.

Burgos-Rosas R., Pérez-Pérez L. 2006: Mero. In: Arreguín-Sánchez F., Meléndez-Moreno L., Méndez-Gómez-Humarán I., SolanaSansores R., Rangel-Dávalos C. (eds), Sustentabilidad y Pesca Responsable en México: Evaluación y Manejo. Instituto Nacional de la Pesca, Secretaria de Agricultura, Ganadería, Desarrollo Rural, Pesca y Alimentación, México, pp. 503-522.

Caswell H. 1988. Approaching size and age in matrix population models. In: Ebenman E., Persson L. (eds), Size-structured populations. Springer-Verlag, Berlin, Heidelberg, pp. 85-105

Coleman F.C., Koenig C.C., Collins L.A. 1996. Reproductive styles of shallow-water groupers (Pisces: Serranidae) in the eastern Gulf of Mexico and the consequences of fishing spawning ag- gregations. Environ. Biol. Fishes. 47: 129-141.

Cressie N.A.C. 1991. Statistics for Spatial Data. John Wiley and Sons Inc, New York, 920 pp.

Domeier M.L., Colin P.L. 1997. Tropical reef fish spawning aggregations: defined and reviewed. Bull. Mar. Sci. 60: 698-726.

Ehrhardt N.M., Deleveaux V.K.W. 2007. The Bahamas' Nassau grouper (Epinephelus striatus) fishery-two assessment methods applied to a data-deficient coastal population. Fish. Res. 87: $17-27$.

García C. 1976. Utilización del pronóstico de temperatura para las operaciones pesqueras en el norte del Banco de Campeche. Rev. Invest. INP. 2: 126-132.

Giménez E., Moreno V., Burgos R., Alfonso S. 2003. Reproducción y fecundidad de la cherna americana (Epinephelus morio) en el banco de Campeche, México. Oceánides 18: 13-22.

Giménez-Hurtado E. 2005. Análisis de la pesca del mero Epinephelus morio (Serranidae: Pisces, Valenciennes 1928) en el Banco de Campeche. Ph.D. thesis, Centro de Investigaciones Biológicas del Noroeste, México, 93 pp.

González P., Zupanovic S., Ramis H. 1974. Evaluación de los niveles de explotación de la cherna americana en el Banco de Campeche. Res. Invest. INP/CIP. Cuba. 1: 172-175.

Hernández A., Seijo J.C. 2003. Spatial distribution analysis of red grouper (Epinephelus morio) fishery in Yucatan, Mexico. Fish. Res. 63: 135-141.

Huse G., Giske J. 1998. Ecology in Mare Pentium: an individualbased spatio-temporal model for fish with adapted behavior. Fish. Res. 37: 163-178.

López-Rocha J.A., Arreguín-Sánchez F. 2008. Spatial distribution of red grouper Epinephelus morio (Serranidae) catchability on the Campeche Bank of Mexico. J. Appl. Ichthyol. 24: 282-289.

López-Rocha J.A., Albañez-Lucero M.O., Arreguín-Sánchez F., de Anda-Montañez J.A. 2009. Analysis of the spatial and seasonal variation in catchability of red grouper, Epinephelus morio, in the Campeche Bank before overfishing (1973-1977). Rev. Biol. Mar. Oceanogr. 44: 751-761.

MacCall A. 1990. Dynamic geography of marine fish populations. University of Washington Press. Books in recruitment fishery oceanography. $153 \mathrm{pp}$.

Moe M.A. 1969. Biology of the red grouper, Epinephelus morio (Valenciennes), from the eastern Gulf of México. Fla. Bd. Conserv. Mar. Lab. Prof. Pap. Ser. 10: 1-95.

Okunishi T., Ito S., Ambe D., Takasuka A., Kameda T., Tadokoro K., Setou T., Komatsu K., Kawabata A., Kubota H., Ichikawa T., Sugisaki H., Hashioka T., Yamanaka Y., Yoshie N., Watanabe T. 2012. A modeling approach to evaluate growth and movement for recruitment success of Japanese sardine (Sardinops melanostictus) in the western Pacific. Fish. Oceanogr. 21: 44-57.

Piñeiro R., Giménez E. 2001. Características térmicas del Banco de Campeche. Cienc. Pesq. 15: 83-87.

Polacheck T., Paige J., Laslett G.M. 2010. Classifying tagging experiments for commercial fisheries into three fundamental types based on design, data requirements and estimable population parameters. Fish Fish. 11: 133-148.

Renán X., Cervera-Cervera K., Brulé T. 2003. Probable nursery areas for juvenile groupers along the northern coast of the Yucatan peninsula, Mexico. Proc. Gulf Caribb. Fish. Inst. 54: 496-505.

Rivas L.R. 1970. The red grouper of the Gulf of Mexico. Commer. Fish. Rev. 32: 24-30.

Sadovy Y. 1996. Reproduction of reef fish species. In: Polunin N.V.C., Roberts C.M. (eds), Reef Fisheries. Chapman and Hall, London, pp. 15-59.

Schaefer M.B. 1954. Some aspects of the dynamics of populations important to the management of the commercial marine fisheries. Bull. Inter-Am. Trop. Tuna Comm. 1: 27-56.

Schaefer M.B. 1957. A study of the dynamics of the fishery for yellow fin tuna in the eastern tropical Pacific Ocean. Bull. InterAm. Trop. Tuna Comm. 2: 247-268.

Shapiro D. 1987. Reproduction in groupers. In: Polovina J.J., Ralston S. (eds), Tropical snappers and groupers: Biology and Fisheries Management. Westview Press, Boulder and London, pp. $295-325$

Shepherd J.G. 1987. A weakly parametric method for estimating growth parameters from length composition data. In: Pauly D., Morgan G.P. (eds), Length based methods in fisheries research. ICLARM Conf. Proc. 14, pp. 113-119. 
322 • J.A. López-Rocha and F. Arreguín-Sánchez

Sluka R., Chiappone M., Sullivan K.M. 1994. Comparison of juvenile grouper populations in southern Florida and the central Bahamas. Bull. Mar. Sci. 54: 871-880.

Valdés E., Padrón G. 1980. Pesquerías de palangre. Rev. Cub. Inv. Pesq. 5: 38-52.

Vasiliev G.D., Serrano F. 1973. Régimen térmico de las aguas del banco de Campeche. Inf. Invest. pp. 1-22.
Zetina-Moguel C., Ríos V., Contreras M. 1996. Notas sobre la reproducción de mero (Epinephelus morio) en el Banco de Campeche, Golfo de México. Cienc. Pesq. 13: 27-29.

Scient. ed.: F. Maynou.

Received January 11, 2012. Accepted February 8, 2013.

Published online March 13, 2013. 